\title{
Kajian C-Organik Gambut Pedalaman pada Berbagai Tutupan Lahan
}

\author{
Alpandi Edison Pardede ${ }^{1}$, Nina Yulianti ${ }^{2}$, Akhmat Sajarwan², Sustiyah ${ }^{2}$, Fengky Florante Adji ${ }^{2}$ \\ ${ }^{1)}$ Mahasiswa Jurusan Budidaya Pertanian, Fakultas Pertanian, Universitas Palangka Raya \\ ${ }^{2)}$ Tenaga Pengajar, Jurusan Budidaya Pertanian, Fakultas Pertanian, Universitas Palangka Raya \\ Email: ${ }^{2}$ nyulianti@agr.upr.id
}

\begin{abstract}
The study aims to identify the C-organic content of inland peat in various land cover and soil layer depths. This study uses plot sampling methods with the creation of minipits on 4 (four) types of land cover. In each type of land cover, there are 3 (three) plot sampling, so the total plot sampling is 12 fields. Soil sampling is carried out at depths of 0-10 $\mathrm{cm}, 10-20 \mathrm{~cm}, 20-30 \mathrm{~cm}, 30-40 \mathrm{~cm}$, and 40-50 cm. The research site is in the Special Purpose Forest Area (KHDTK) of Nusa Natural Laboratory and Peat Forest (LAHG) Sebangau. The study was conducted from June to August 2021. Soil samples are analyzed at the UPT Laboratory. LLG-Cimtrop and UPT. Integrated Laboratory, Palangka Raya University. The parameters observed are C-organic, Ash content, Moisture content, Water content, and Fiber content. The data of the study results are analyzed statistically with regression and correlation analysis. The results showed that the land cover that has the highest C-organic content is land revegetation (RePeat) at a depth of $40-50 \mathrm{~cm}$ with a Corganic value of $57.81 \%$ and the lowest C-organic content in natural forest cover at a depth of $30-40 \mathrm{~cm}$ with a Corganic value of $52.2 \%$. The highest ash content is in natural forest cover at a depth of $30-40 \mathrm{~cm}$ with an ash content value of 3.18\% and the lowest ash content in land cover revegetation (RePeat) at a depth of 40-50 cm with an ash level value of $0.08 \%$. The highest water content is in the revegetation of land cover (RePeat) at a depth of $40-50 \mathrm{~cm}$ with a water content value of $318.97 \%$ and the lowest water content in the burned land cover at a depth of $0-10 \mathrm{~cm}$ with a water content value of $92.56 \%$.
\end{abstract}

Keywords: C-organic, Soil Properties, Inland Peat, Land Cover.

\section{Pendahuluan}

Lahan gambut adalah lapisan tanah yang tersusun oleh bahan organik (C-organik > 18\%), memiliki ketebalan $\pm 50 \mathrm{~cm}$, terbentuk dari sisa-sisa tanaman yang belum melapuk sempurna karena kondisi lingkungan jenuh air, dan sedikit unsur hara (Agus, 2008). Peranan lahan gambut terhadap lingkungan sangat penting, salah satunya sebagai lahan yang mampu menyimpan karbon dalam jangka waktu yang lama. Karbon yang tersimpan pada tutupan lahan berbeda, tergantung keragaman dan kerapatan tumbuhan yang ada, jenis tanahnya serta pengelolaanya. Lahan gambut secara keseluruhan diperkirakan sebesar sepertiga dari lahan basah global (Parish et al., 2008) dan merupakan ekosistem penting untuk konservasi keanekaragaman hayati, pengaturan iklim, dan kesejahteraan manusia (Erwin, 2009). Sekitar 31-46 Mha lahan gambut (10-12\% dari luas lahan gambut global) ditemukan di negara-negara tropis (Maltby dan Proctor 1996). Di antara negara-negara tersebut, Indonesia memiliki lahan gambut tropis terluas (sekitar 20,6 Mha) (Immirzi et al. 1992, Rieley et al. 1996, Page et al. 2011), terutama terletak di pulau Sumatra, Kalimantan (Kalimantan) dan Papua (Purnomo et al., 2019). Dalam kondisi alaminya, lahan gambut ini menyediakan jasa lingkungan yang penting secara global, terutama terkait dengan perubahan iklim karena kapasitas penyimpanan karbon yang sangat besar (Page et al., 2011).

Hasil penelitian mendapatkan bahwa, konversi lahan gambut yang terjadi di Asia Tenggara seluas 10 Mha akan menghasilkan emisi C 132-159 Mt tahun $^{-1}$ dari oksidasi gambut dan peningkatan kejadian kebakaran lahan gambut yang tidak hanya menambah emisi GRK tetapi juga mengancam kesehatan dan mata pencaharian manusia (Marlier et al., 2013). Selain itu, hilangnya gambut melalui oksidasi dan kebakaran mengakibatkan penurunan permukaan tanah dan peningkatan risiko banjir (Hooijer et al., 2012; Evers et al., 2016).

Penyimpanan karbon suatu lahan menjadi lebih besar bila kondisi kesuburan tanahnya baik, atau dengan kata lain jumlah karbon tersimpan diatas tanah (biomassa tanaman) ditentukan oleh besarnya jumlah 
karbon tersimpan di dalam tanah (bahan organik tanah) untuk itu pengukuran banyaknya karbon yang di timbun dalam setiap lahan perlu dilakukan (Hairiah dan Rahayu, 2007). Karbon adalah komponen utama dari bahan organik. Pengukuran C-organik secara tidak langsung dapat menentukan bahan organik melalui penggunaan faktor koreksi tertentu. Faktor yang selama beberapa tahun ini digunakan adalah faktor van bemmelen yaitu 1,724 atau didasarkan pada asumsi bahwa bahan organik mengandung 58\% karbon (Mukhlis, 2014).

Penelitian ini bertujuan untuk mengindentifikasi kandungan C-organik gambut pedalaman pada berbagai tutupan lahan dan kedalaman lapisan tanah.

\section{Metode Penelitian}

Penelitian ini dilaksanakan selama 3 bulan dimulai dari Juni sampai dengan Agustus 2021. Sampel gambut diambil dari lokasi dengan tipe tutupan lahan yang berbeda, yaitu: 1). lahan hutan alami, 2). hutan sekunder, 3). lahan berkas terbakar, dan 4). lahan revegetasi (RePeat). Pengambilan sampel tanah 1 (satu) tipe tutupan lahan yaitu lahan hutan alami bertempat di Laboratorium Alam Hutan Gambut (LAHG) seperti pada Gambar 1. Sebangau dan 3 (tiga) tipe tutupan lahan yaitu hutan sekunder, lahan bekas terbakar dan lahan gambut revegetasi (RePeat) bertempat di Kawasan Hutan dengan Tujuan Khusus (KHDTK) Tumbang Nusa seperti pada Gambar 2. Analisis sampel tanah dilakukan di Laboratorium UPT LLG-Cimtrop Universitas Palangka Raya, dan UPT. Laboratorium Terpadu, Universitas Palangka Raya.

Di setiap tipe tutupan lahan terdapat 3 (tiga) plot sampling, sehingga total plot pengambilan sampel adalah 12 plot. Pengambilan sampel tanah dilakukan pada kedalaman 0-10 cm, 10-20 cm, 20-30 cm, 30-40 $\mathrm{cm}$, dan 40-50 cm. Penelitian ini menggunakan metode minipit dengan ukuran $120 \mathrm{~cm}$ x $120 \mathrm{~cm}$. Minipit dibuat seperti penampang tanah (profil), tetapi ukuran lebih kecil dan lebih dangkal.

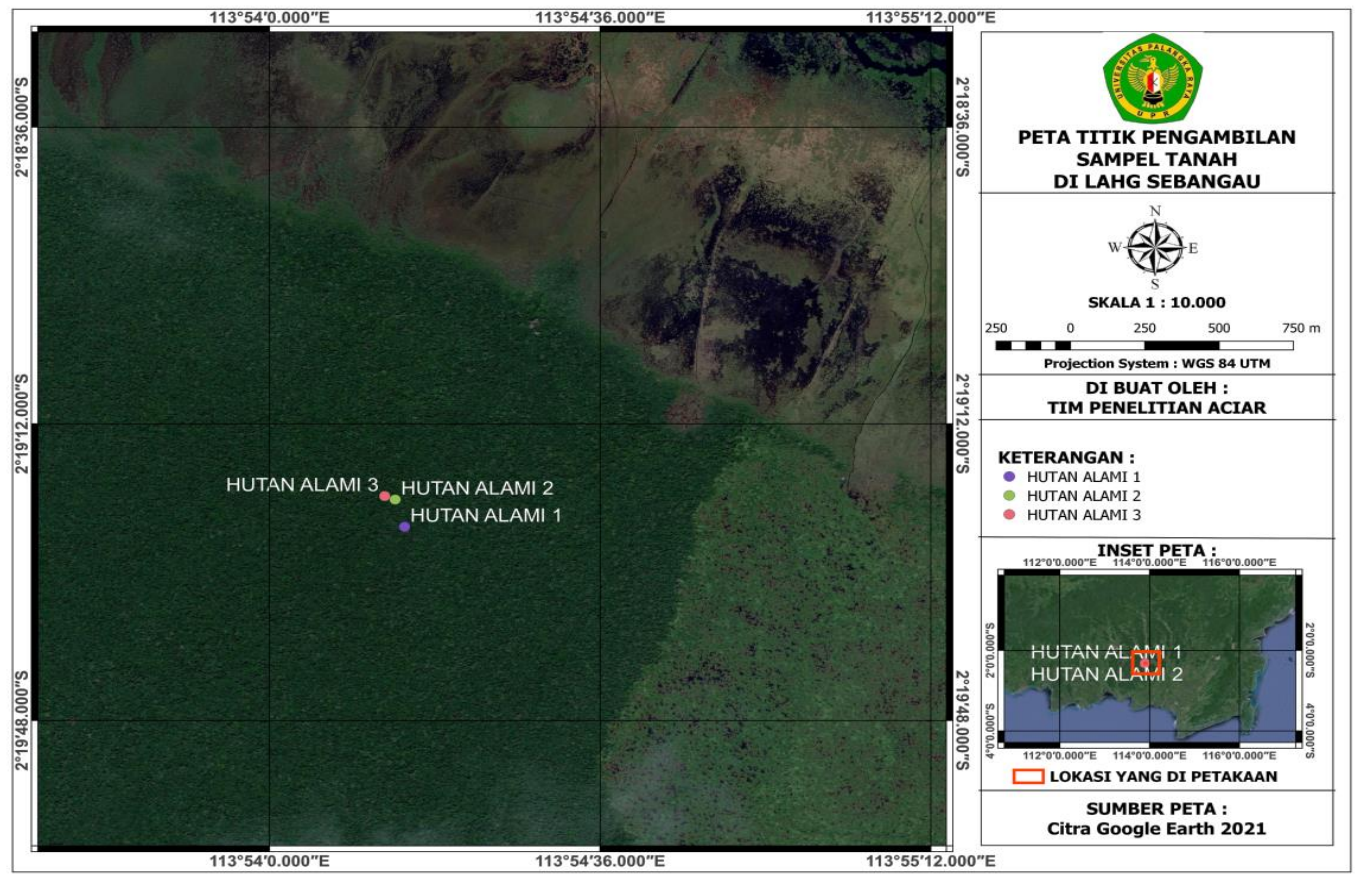

Gambar 1. Peta Pengambilan Sampel Tanah di LAHG Sebangau 


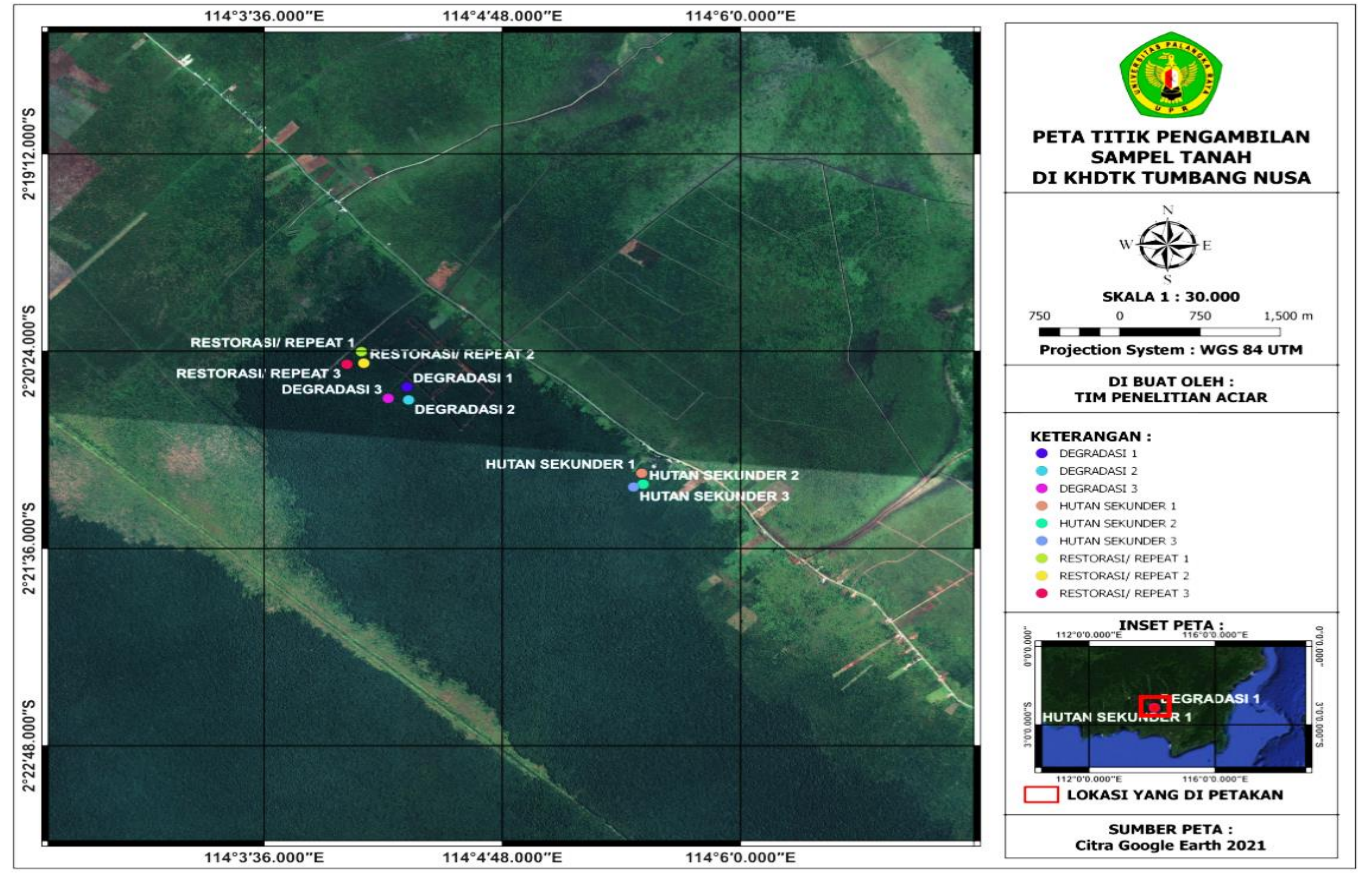

Gambar 2. Peta Pengambilan Sampel Tanah di KHDTK Tumbang Nusa

\section{Hasil Dan Pembahasan}

\section{Hasil Analisis Kandungan C-organik (\%)}

Hasil penelitian ini mendapatkan bahwa, kandungan C-organik yang paling tinggi terdapat pada kedalaman 40-50 cm pada tutupan lahan revegetasi (RePeat) dengan nilai C-organik adalah 57,81\%, dan kandungan C-organik yang paling rendah terdapat pada kedalaman 30-40 $\mathrm{cm}$ pada tutupan hutan alami dengan nilai C-organik adalah 52,2\%. (Gambar 3).

C-organik pada lapisan permukaan $(40-50 \mathrm{~cm})$, lahan revegetasi (RePeat) mempunyai kandungan rata-rata $\mathrm{C}$-organik yang paling tinggi, yaitu $57,81 \%$ dan yang paling rendah terdapat di lahan bekas terbakar dengan rata-rata, yaitu 57,58\%. Berdasarkan hasil penelitian dari Prasetya (2019) pembukaan lahan secara besar-besaran hingga kebakaran hutan, selain itu peningkatan bahan organik juga berasal dari bahan bakar sisa pembakaran. Hal tersebut memungkinkan terjadinya penumpukan bahan organik sehingga pada lahan revegetasi memiliki kadar C-organik yang tinggi. Semakin tinggi tingkat kedalaman gambut, maka kandungan karbon di dalamnya juga akan semakin tinggi. Selain itu, tingginya kandungan C-organik juga dapat dipengaruhi oleh tingkat kematangan dan kadar abu (Agus dan Subakti, 2008). Hasil penelitian yang dilakukan oleh Saleilei (2021), mendapatkan kandungan C-organik yang rendah pada lahan bekas terbakar, hal ini disebabkan oleh terjadinya kebakaran yang menyebabkan hilangnya kandungan bahan organik di dalam tanah dan terganggunya proses dekomposisi tanah gambut karena mikroorganisme yang mati akibat kebakaran.

C-organik pada lapisan permukaan $(30-40 \mathrm{~cm})$, lahan revegetasi (RePeat) mempunyai kandungan rata-rata $\mathrm{C}$-organik yang paling tinggi, yaitu $57,77 \%$ dan yang paling rendah terdapat di hutan alami dengan rata-rata, yaitu 52,2\% Berdasarkan hasil penelitian dari Prasetya (2019) pembukaan lahan secara besarbesaran hingga kebakaran hutan, selain itu peningkatan bahan organik juga berasal dari bahan bakar sisa pembakaran. Hal tersebut memungkinkan terjadinya penumpukan bahan organik sehingga pada lahan revegetasi memiliki kadar $\mathrm{C}$-organik yang tinggi. C-organik paling rendah terdapat di hutan alami 
dikarenakan kondisi hutan alami pada saat pengambilan sampel tergenang, dan menyebabkan bahan organik yang berada di hutan menjadi sangat lambat terdekomposisi secara sempurna karena kondisi tergenang.

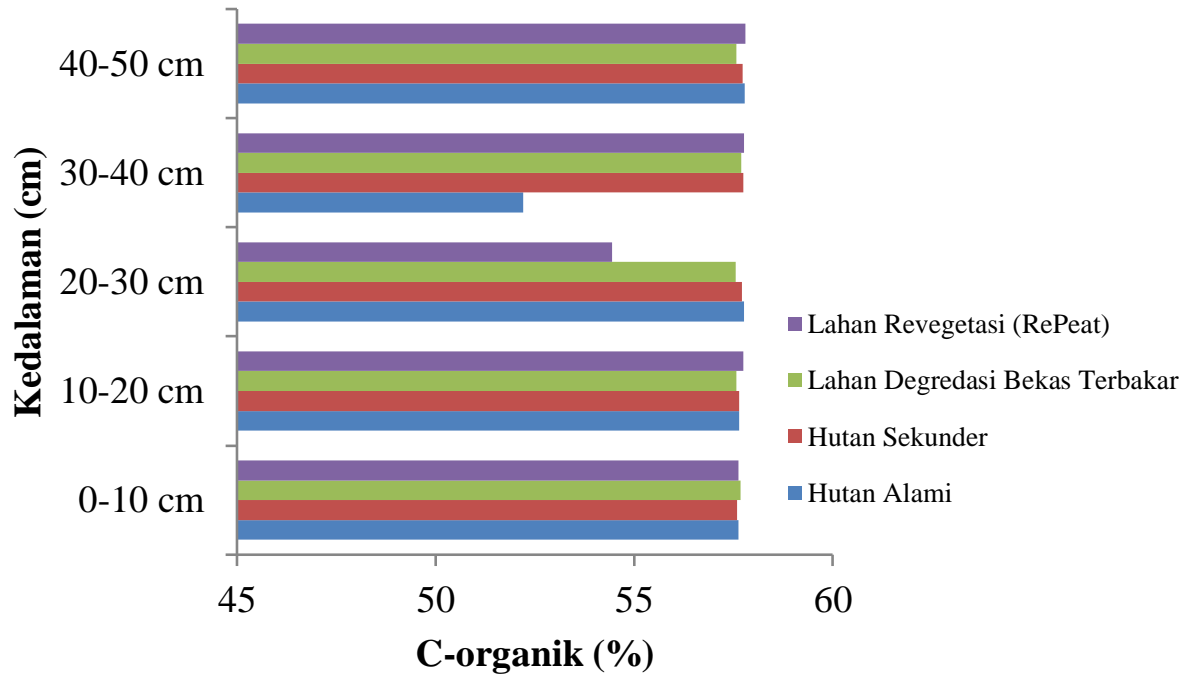

Gambar 3. C-Organik Berbagai Kedalaman Lapisan Gambut pada Tutupan Lahan Berbeda

\section{Hasil Analisis Kandungan Kadar Abu (\%)}

Hasil penelitian mendapatkan kandungan kadar abu paling tinggi terdapat pada kedalaman $30-40 \mathrm{~cm}$ pada tutupan hutan alami dengan nilai kadar abu adalah 3,18\%, dan kadar abu paling rendah terdapat pada kedalaman 40-50 cm pada tutupan lahan revegetasi (RePeat) dengan nilai kadar abu adalah 0,08\%. Untuk jelasnya dapat dilihat pada Gambar 4.

Kadar abu pada lapisan permukaan $(30-40 \mathrm{~cm})$, hutan alami mempunyai kandungan rata-rata kadar abu yang paling tinggi, yaitu $3,18 \%$, dan yang paling rendah terdapat di lahan revegetasi (RePeat) dengan rata-rata, yaitu 0,1\%.Berdasarkan hasil penelitian Pratama (2019) tingginya kadar abu pada hutan alami dikarenakan pada lokasi ini keadaan lahan tidak tergenang, karena adanya drainase dan konveksi/pemadatan tanah gambut sehingga gambut menjadi tidak tergenang dan sampel tanah gambut lebih kering, dan tidak banyak menyimpan air berlebihan, dan adanya pemberian amelioran pada gambut diduga membuat tanah gambut lebih cepat melakukan dekomposisi. Kadar abu paling rendah terdapat pada lahan revegetasi (RePeat) dikarenakan ketika pengambilan sampel gambut kondisi lahan tergenang. Sehingga dekomposisi gambut berjalan sangat lambat dan lahan masih bersifat jenuh air atau anaeorob sehingga aktivitas mikroorganisme sebagai decomposer menjadi terhambat. Presentasi nilai kadar abu dan C-organik berbanding terbalik. Kadar abu tinggi mengindikasi bahwa C-organik rendah, dan apabila C-organik tinggi maka kandungan kadar abu akan semakin rendah.

Kadar abu pada lapisan permukaan $(40-50 \mathrm{~cm})$, hutan sekunder mempunyai kandungan rata-rata kadar abu yang paling tinggi, yaitu $0,21 \%$, dan yang paling rendah terdapat di lahan revegetasi (RePeat) dengan rata-rata, yaitu 0,08\%. Berdasarkan hasil penelitian Pratama (2019) tingginya kadar abu pada hutan sekunder dikarenakan pada lokasi ini keadaan lahan tidak tergenang, karena adanya drainase dan konveksi/pemadatan tanah gambut sehingga gambut menjadi tidak tergenang dan sampel tanah gambut lebih kering, dan tidak banyak menyimpan air berlebihan, dan adanya pemberian amelioran pada gambut diduga membuat tanah gambut lebih cepat melakukan dekomposisi. Kadar abu paling rendah terdapat pada lahan revegetasi (RePeat) dikarenakan ketika pengambilan sampel gambut kondisi lahan tergenang. Sehingga dekomposisi gambut berjalan sangat lambat dan lahan masih bersifat jenuh air atau anaeorob sehingga aktivitas mikroorganisme sebagai decomposer menjadi terhambat. Persentase nilai kadar abu dan 
C-organik berbanding terbalik. Kadar abu tinggi mengindikasi bahwa C-Organik rendah, dan apabila Corganik tinggi maka kandungan kadar abu akan semakin rendah.

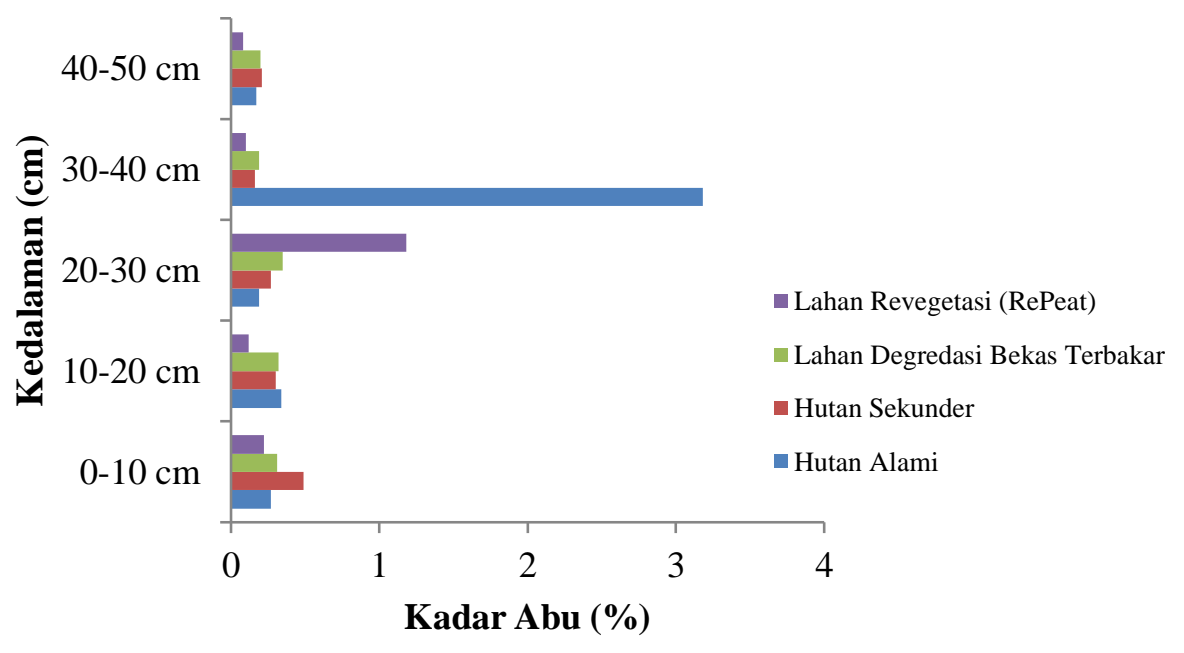

Gambar 4. Kadar Abu Berbagai Kedalaman Lapisan Gambut pada Tutupan Lahan Berbeda

\section{Hasil Analisis Kandungan Kadar Air (\%)}

Hasil penelitian mendapatkan kadar air paling tinggi terdapat pada kedalaman 40-50 cm pada tutupan lahan revegetasi (RePeat) dengan nilai C-Organik adalah 318,97\%, dan kadar air paling rendah terdapat pada kedalaman 0-10 cm pada tutupan lahan berkas terbakar dengan nilai kadar air adalah 92,56\%. Untuk jelasnya dapat dilihat pada Gambar 5.

Kadar air pada lapisan permukaan $(40-50 \mathrm{~cm})$, lahan revegetasi (RePeat) mempunyai kandungan ratarata kadar air yang paling tinggi, yaitu $318,97 \%$, dan yang paling rendah terdapat di hutan sekunder dengan rata-rata, yaitu $122,64 \%$. Hal ini diduga karena tingginya curah hujan pada saat penelitian sehingga menyebabkan kondisi lahan kelebihan air dan adanya saluran drainase yang tergenang, hal ini mempengaruhi kadar air pada gambut. Selain itu, tingkat kematangan gambut juga mempengaruhi tinggi rendahnya kadar air tanah. Pada tingkat kematangan gambut saprik yang kelebihan air menyebabkan gambut dalam kondisi anaerob sehingga kemampuan menyimpan air cukup tinggi. Menurut Wibowo (2009 dalam Setiadi, 2016) bahwa dalam keadaan jenuh gambut saprik mampu menyimpan air sebanyak 450\%. Daya menyimpan air yang tinggi menjadikan gambut berfungsi sebagai pencegah intrusi air laut ke daratan. Kadar air paling rendah terdapat pada hutan sekuder dikarenakan terjadinya konveksi atau merapatnya antar partikel-partikel tanah gambut yang menyebabkan penyempitan pori makro dan pori mikro yang menyebabkan turunnya kemampuan gambut untuk menjerap air.

Kadar air pada lapisan permukaan $(0-10 \mathrm{~cm})$, lahan revegetasi (RePeat) mempunyai kandungan ratarata kadar air yang paling tinggi, yaitu $201,4 \%$, dan yang paling rendah terdapat di lahan bekas terbakar dengan rata-rata, yaitu 92,56\%. Hal ini diduga karena tingginya curah hujan pada saat penelitian sehingga menyebabkan kondisi lahan kelebihan air dan adanya saluran drainase yang tergenang, hal ini mempengaruhi kadar air pada gambut. Selain itu, tingkat kematangan gambut juga mempengaruhi tinggi rendahnya kadar air tanah. Pada tingkat kematangan gambut saprik yang kelebihan air menyebabkan gambut dalam kondisi anaerob sehingga kemampuan menyimpan air cukup tinggi. Menurut Wibowo (2009 dalam Setiadi, 2016) bahwa dalam keadaan jenuh gambut saprik mampu menyimpan air sebanyak 450\%. Daya menyimpan air yang tinggi menjadikan gambut berfungsi sebagai pencegah intrusi air laut ke daratan. Kadar air paling rendah terdapat pada lahan bekas terbakar dikarenakan tinggi muka air tanahnya berada di bawah permukaan tanah sehingga ketersediaan oksigen dalam tanah cukup tinggi (Sinaga, 2017). 


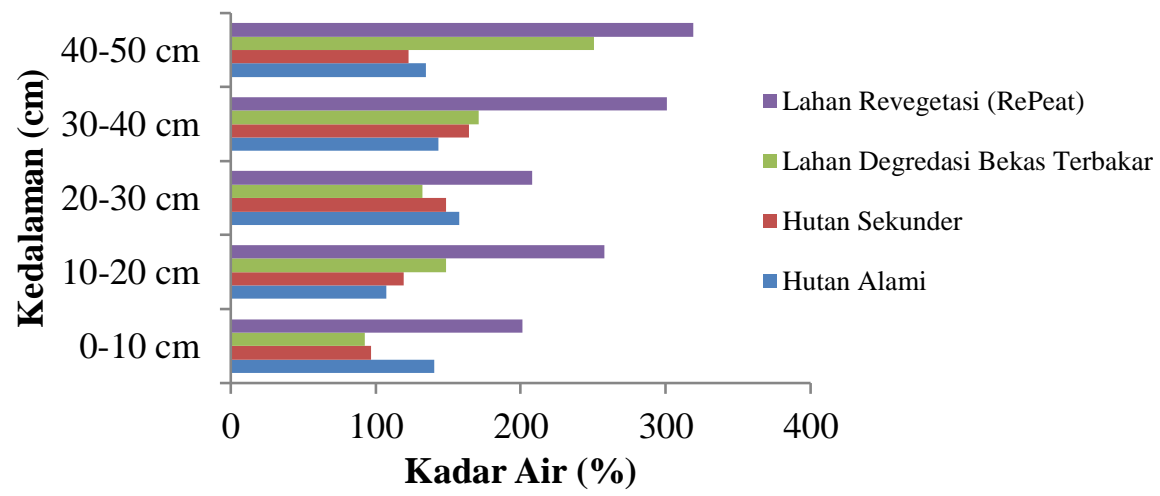

Gambar 5. Kadar Air Berbagai Kedalaman Lapisan Gambut pada Tutupan Lahan Berbeda

\section{Hasil Analisis Kandungan Kadar Serat (\%) dan Kematangan Gambut}

Hasil penelitian mendapatkan kadar serat paling tinggi terdapat pada kedalaman 0-10 cm pada tutupan hutan alami mempunyai kandungan rata-rata kadar serat adalah 50,67\% dengan kematangan saprik, dan kadar serat paling rendah terdapat di lahan revegetasi (RePeat) dengan kematangan rata-rata hemik adalah 10,67\%. Untuk jelasnya dapat dilihat pada Tabel 1.

Hasil analisis menunjukkan bahwa kandungan kadar serat pada lapisan permukaan $(0-10 \mathrm{~cm})$, hutan alami mempunyai kandungan rata-rata kadar serat yang paling tinggi, yaitu 50,67\% dengan kematangan saprik dan yang paling rendah terdapat di lahan revegetasi (RePeat) dengan kematangan rata-rata hemik, yaitu $10,67 \%$. Hal ini dikarenakan tanah diambil dari lapisan olah tanah di daerah persebaran akar pada lapisan topsoil dan kondisi dalam keadaan aerob sehingga akan meningkatkan jumlah aktivitas mikroorganisme dalam dekomposisi tanah gambut. Kadar serat menunjukkan bahwa tingkat kematangan gambut di daerah penelitian dibedakan menjadi 2 (dua) jenis, yaitu gambut saprik dan hemik. Gambut saprik adalah gambut yang tingkat pelapukannya sudah lanjut (matang). Gambut hemik adalah gambut yang mempunyai tingkat pelapukan sedang (setengah matang), sebagian bahan telah mengalami pelapukan dan sebagian lagi berupa serat. Dijelaskan oleh Najiyati et al. (2005), tingkat kematangan gambut bervariasi karena terbentuk dari bahan, kondisi lingkungan, dan waktu yang berbeda. Gambut yang telah matang akan cenderung lebih halus dan lebih subur. Sebaliknya yang belum matang, banyak mengandung serat dan kurang subur.

Tabel 1. Hasil Analisis Kadar Serat dan Kematangan Gambut

\begin{tabular}{|c|l|c|c|}
\hline No. & \multicolumn{1}{|c|}{ Tutupan Lahan } & Kadar Serat (\%) & Kematangan Gambut \\
\hline 1 & Hutan Alami & 45,34 & Hemik \\
\hline 2 & Hutan Sekunder & 14,67 & Saprik \\
\hline 3 & Lahan Bekas Terbakar & 14,40 & Saprik \\
\hline 4 & Lahan Revegetasi (RePeat) & 15,20 & Saprik \\
\hline
\end{tabular}

Keterangan: Menurut Turnip (2018) menyatakan bahwa gambut dengan tingkat kematangan saprik memiliki volume kadar serat lebih kecil dari (<33\%), tingkat kematangan hemik memiliki volume kadar serat sebesar 33-67\% dan tingkat kematangan fibrik memiliki nilai kadar serat lebih besar dari (>67).

\section{Hubungan C-Organik dengan Kadar Abu}

Berdasarkan Gambar 6, hubungan antara kandungan C-organik dengan kadar abu berkorelasi negatif $(\mathrm{r}=-0,97)$ dengan persamaan $\mathrm{y}=-0,4774 \mathrm{x}+27,763$. Grafik menunjukkan pola hubungan terbalik antara. C-organik dengan kadar abu. Semakin tinggi kadar C-organik maka kadar abu semakin rendah pada lahan 
gambut. Hal ini disebabkan bahan organik yang tinggi (akumulasi bahan organik tinggi). Menurut Agus et al., 2011 dalam Sigalingging, 2018) tingkat kematangan yang tinggi menunjukan bahwa tingkat dekomposisi yang semakin sempurna yang akan meningkatkan kadar abu gambut dan menurunkan komposisi karbonya.

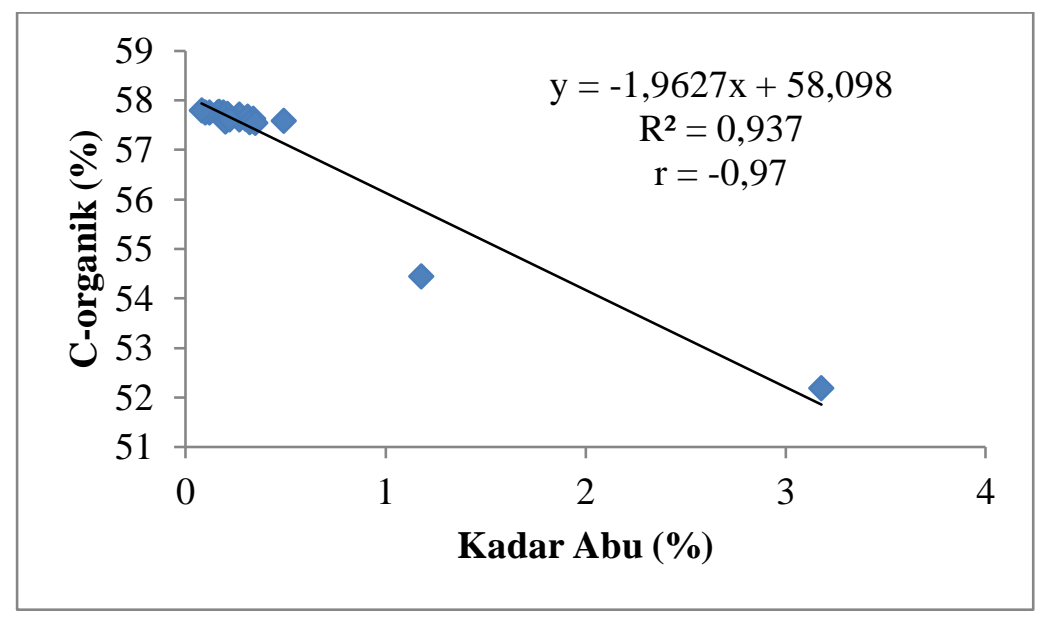

Gambar 6. Grafik Regresi dan Korelasi C-organik dengan Kadar Abu pada Tutupan Lahan Berbeda

\section{Hubungan C-organik dengan Kadar Air}

Berdasarkan Gambar 7, hubungan antara C-organik dengan kadar air berkorelasi positif $(\mathrm{r}=0,04)$ dengan persamaan $y=0,0009 x+57,102$. Grafik menunjukkan pola hubungan sangat lemah antara C-organik dengan kadar air. Hal ini berkaitan dengan hasil analisis C-organik yang lebih tinggi terdapat dekat saluran drainase artinya, meskipun kondisinya lebih aerobik dekat saluran drainase namun proses dekomposisi bahan gambut tidak terjadi secara intensif. Hal ini disebabkan oleh tingkat kematangan pada tutupan lahan berbeda (hemik - saprik), sehingga proses dekomposisi berjalan lambat sebagai akibat material gambut sudah mendekati ukuran halus dan bersifat menolak air (hidrofobik). Hal ini sejalan dengan pernyataan Sabiham (2000), penurunan kemampuan gambut menyerap air berkaitan dengan penuruan ketersediaan gugus karboksilat dan $\mathrm{OH}-$ fenolat dalam bahan gambut. Kedua komponen organik ini merupakan senayawa yang bersifat hidrofilik.

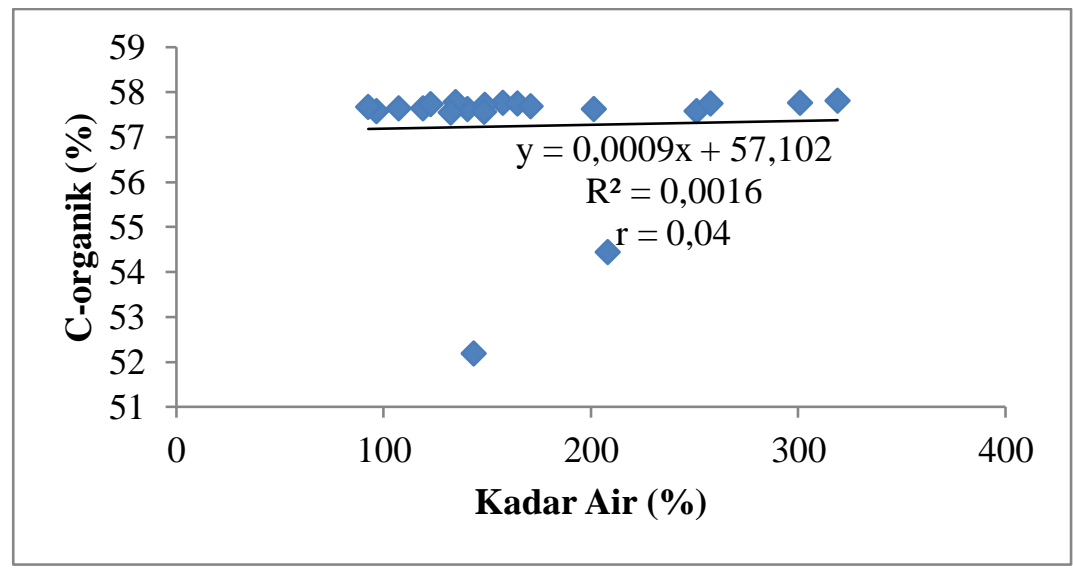

Gambar 7. Grafik Regresi dan Korelasi C-organik dengan Kadar Air pada Tutupan Lahan Berbeda 


\section{Hubungan C-Organik dengan Kadar Serat}

Berdasarkan Gambar 8, hubungan antara C-organik dengan kadar serat berkorelasi negatif $(\mathrm{r}=-0,31)$ dengan persamaan $y=-0,03 x+57,921$. Grafik menunjukkan pola hubungan terbalik antara C-organik dengan kadar serat. Hal ini menunjukkan bahwa tindakan pengelolaan lahan gambut dalam jangka waktu yang lebih lama dapat mempercepat pematangan bahan gambut karena drainase dan pemupukan sehingga kadar serat semakin menurun.

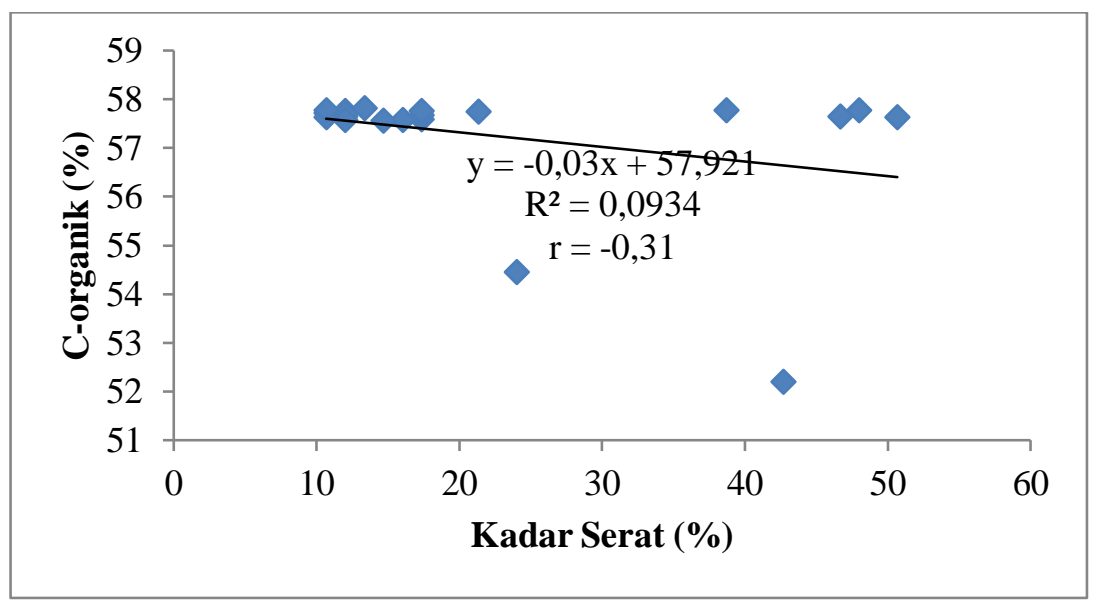

Gambar 8. Grafik Regresi dan Korelasi C-organik dengan Kadar Serat pada Tutupan Lahan Berbeda

\section{Kesimpulan dan Saran}

Berdasarkan hasil penelitian maka dapat disimpulkan bahwa kandungan C-organik paling tinggi terdapat pada kedalaman 40-50 $\mathrm{cm}$ pada tutupan lahan revegetasi (RePeat) dengan nilai C-organik adalah $57,81 \%$, dan kandungan C-organik paling rendah terdapat pada kedalaman 30-40 cm pada tutupan hutan alami dengan nilai C-organik adalah 52,2\%. Kadar abu paling tinggi terdapat pada kedalaman $30-40 \mathrm{~cm}$ pada tutupan hutan alami dengan nilai kadar abu adalah 3,18\%, dan kadar abu paling rendah terdapat pada kedalaman 40-50 cm pada tutupan lahan revegetasi (RePeat) dengan nilai kadar abu adalah 0,08\%. Kadar air paling tinggi terdapat pada kedalaman $40-50 \mathrm{~cm}$ pada tutupan lahan revegetasi (RePeat) dengan nilai Corganik adalah $318,97 \%$, dan kadar air paling rendah terdapat pada kedalaman 0-10 cm pada tutupan lahan berkas terbakar dengan nilai kadar air adalah 92,56\%. Kadar serat paling tinggi terdapat pada kedalaman 0$10 \mathrm{~cm}$ pada tutupan hutan alami mempunyai kandungan rata-rata kadar serat adalah 50,67\% dengan kematangan saprik, dan kadar serat paling rendah terdapat di lahan revegetasi (RePeat) dengan kematangan rata-rata hemik adalah 10,67\%. Hubungan C-Organik dengan kadar abu adalah hubungan terbalik. Semakin tinggi kadar C-Organik maka kadar abu semakin rendah pada gambut. Hubungan C-organik dengan kadar air adalah pola hubungan sangat lemah antara C-Organik dengan kadar air. Hubungan C-organik dengan kadar serat adalah pola hubungan terbalik antara C-Organik dengan kadar serat. Pengambilan sampel gambut sebaiknya dilakukan pada tiga (3) tipologi lahan gambut, yaitu: lahan gambut pedalaman, lahan gambut transisi dan lahan gambut pantai.

\section{Ucapan Terima Kasih}

Ucapan terima kasih disampaikan kepada the Australian Centre for International Agricultural Research (ACIAR) dan the Commonwealth Scientific and Industrial Research Organisation (CSIRO), Australia. Penelitian ini dibiayai penuh oleh Objective 3 (tiga) FST/2016/144 Improving Community Fire Management and Peatland Restoration in Indonesia dengan Memorandum of Understanding (MoU) ACIAR/CSIRO dan Universitas Palangka Raya. 


\section{Daftar Pustaka}

Agus, F. dan I.G.M. Made Subiksa. 2008. Lahan Gambut: Potensi untuk Pertanian dan Aspek Lingkungan. Badan Penelitian dan Pengembangan Pertanian. Balai Penelitian Tanah. Bogor. 36 hal.

Agus, F. dan I.G.M. Made Subiksa. 2008. Lahan Gambut: Potensi untuk Pertanian dan Aspek Lingkungan. Badan Penelitian dan Pengembangan Pertanian. Balai Penelitian Tanah. Bogor. 36 hal.

Agus, F., K. Hairiah, dan A. Mulyani. 2011. Pengukuran Cadangan Karbon Tanah Gambut. World Agroforestry Centre dan Balai Besar Penelitian dan Pengembangan Sumberdaya Lahan Pertanian. Bogor. 58 hal.

Erwin, K.L. 2009. Wetlands and global climate change: the role of wetland restoration in a changing world. Wetlands Ecology and Management, 17, 71-84. https://doi.org/10.1007/ s11273-008-9119-1.

Evers, S., Yule, C.M., Padfield, R., O'Reilly, P., and Varkkey, H. 2016. Keep wetlands wet: the myth of sustainable development of tropical peatlands - implications for policies and management. Global Change Biology, 23(2), 534-549. https://doi.org/10.1111/gcb.13422

Hairiah K, Rahayu S. 2007. Pengukuran 'Karbon Tersimpan' di Berbagai Macam Penggunaan Lahan. Bogor. World Agroforestry Centre - ICRAF, SEA Regional Office, University of Brawijaya, Unibraw, Indonesia. 77 p.

Hooijer, A., Page, S.E., Jauhiainen, J., Lee, W.A., Lu, X.X., Idris, A., and Anshari, G. 2012. Subsidence and carbon loss in drained tropical peatlands. Biogeosciences, 9, 1053-1071. https://doi: 10.5194/bg9-1053-2012.

Immirzi, C.P., Maltby, E., and Clymo, R.S. 1992. The Global Status of Peatlands and their Role in Carbon Cycling. Friends of the Earth, London, 145 pp. ISBN: 1857501055

Maltby, E., and Proctor, M.C.F. 1996. Peatlands: their nature and role in the biosphere. In: Lappalainen, E. (ed.) Global Peat Resources, International Peat Society, Jyväskyla, 11-19.

Marlier, M.E., DeFries, R.S., Voulgarakis, A., Kinney, P.L., Randerson, J.T., Shindell, D.T., Chen, Y., Faluvegi, G. (2013) El Niño and health risks from landscape fire emissions in southeast Asia. Nature Climate Change, 3, 131-136. https://doi:10.1038/nclimate1658

Mukhlis. 2014. Analisis Tanah Tanaman. USU Press. Medan.

Nadjiyati, S, L. Muslihat, dan I. Nyoman N. Suryadiputra. 2005. Panduan Pengelolaan Lahan Gambut untuk Pertanian Berkelanjutan. Proyek Climate Change, Forest and Pentands in Indonesia. Wetlands International-Indonesia Programmed an Wildlife Habitat Canansa. Bogor. Indonesia. 257 hal.

Page, S.E., Rieley, J.O., and Banks, C.J. 2011. Global and regional importance of the tropical peatland carbon pool. Global Change Biology, 17, 798-818. https://doi.org/10.1111/j.1365-2486.2010.02279.x

Prasetya, I. Sifat Spekta UV-VIS Ekstrak Gambut Dengan Natrium Pirofosfat pada Penggunaan Lahan yang Berbeda di Mentangai dan KHDTK Tumbang Nusa. Skripsi. Fakultas Pertanian, Universitas Palangka Raya.

Prasetya, I. Sifat Spekta UV-VIS Ekstrak Gambut Dengan Natrium Pirofosfat pada Penggunaan Lahan yang Berbeda di Mentangai dan KHDTK Tumbang Nusa. Skripsi. Fakultas Pertanian, Universitas Palangka Raya.

Rieley, J.O., Ahmad-Shah, A.A., and Brady, M.A. 1996. The extent and nature of tropical peat swamps. In: Maltby, E., Immirzi, C.P., Safford, R.J. (eds.) Tropical Lowland Peatlands of Southeast Asia: Proceedings of a Workshop on Integrated Planning and Management of Tropical Lowland Peatlands held at Cisarua, Indonesia, 3-8 July 1992, IUCN, Gland, Switzerland, x + 294 pp. 
Sabiham, S. 2000. Kadar air kritis gambut Kalimantan Tengah dalam kaitannya dengan kejadian kering tidak balik. J. Tanah Tropika.11:21-30.

Saleilei, A. A. Studi Kandungan C-organik, Kadar Abu, dan Bobot Isi Tanah Gambut Pedalaman pada Beberapa Penggunaan Lahan di Kawasan Hutan dengan Tujuan Khusus(KHDTK) Tumbang Nusa. Skripsi. Fakultas Pertanian, Universitas Palangka Raya.

Setiadi, I.C. 2016. Evaluasi sifat kimia dan fisik gambut dari beberapa lokasi di Blok C Eks-PLG Kalimantan Tengah. Skripsi. Fakultas Pertanian. Universitas Palangka Raya.

Sinaga, E.N 2017. Laju Pelepasan Karbon Tanah Gambut pada Penggunaan Lahan yang Berbeda. Skripsi. Fakultas Pertanian, Universitas Palangka Raya. 